\title{
地域集会施設の建築設計論における地域と接点をもつ主題とその具体化 公共文化施設の建築設計論における領域構成による地域性とビルディングタイプ(3) \\ THOUGHT ON DESIGN THEORIES OF PUBLIC HALL BY CONTEMPORARY JAPANESE ARCHITECTS
}

Study on regionality from the point of view of space composition and building types in design theories on public architecture (3)

\author{
井上翔太*, 峠昇汰**, 谷川大輔*** \\ Shota INOUE, Shota TOGE and Daisuke TANIKAWA
}

\begin{abstract}
This study is to illustrate thought on regionality from the point of view of space composition in design theories on Public hall by contemporary Japanese architects after the Second World War. Firstly, the contents each design theory on Public hall were analyzed, and several descriptions of "The subject " were extracted. Next, the meaning of these comments was analyzed by applying the method created by Jiro Kawakita. Then, there were drawn a relationship diagram and 5 groups of meaning were found. Next, those meanings were divided into two different types; "Phenomenon value and Physical value". Secondly, the contents each design theory were analyzed again, and several descriptions of "The Realization by space compositon" were extracted. And the space compositions were analyzed. Finally, Between "The subject" and "The Realization by space compositon" were analyzed. Then, 3 Patterns were found. Further, the change of that relationship in terms of time was considered.
\end{abstract}

Keywords : public hall, contemporary Japanese architects, design theories, space composition, regionality, building types 地域集会施設，現代日本の建築家，建築設計論，領域構成，地域性，ビルデ゙イン゙タイ゚

\section{1. 序}

\section{1 本論の目的}

わが国では2011年3月 11 日の東日本大震災以降、地方や地域に注目 が集まっており、より市民に近い新しい公共施設の在り方が模索さ れている ${ }^{\text {注 } 1)}$ 。特に住民の日常生活に最も身近な社会教育施設である 公民館やコミュニテイーゼターといった地域集会施設 ${ }^{\text {注2) }}$ は、災害時における 避難施設としての見直しに加え、日常的にみんなが集まる場所とし て、また復興後の地域エミュテテの再形成の拠点施設としてなど、近年 の公共施設建設における新しい公共性や地域性 ${ }^{\text {注 } 3)}$ に関する議論の中

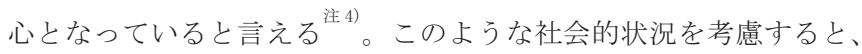
現代の地域集会施設を設計する建築家 ${ }^{\text {注 } 5)}$ は、いかなる水準で地域と 接点をもちうる空間とするかといった、地域における社会的枠組み に関する思考を具体化することが求められていると考えらえる。し かし現代において、地域集会施設を設計する建築家が、こうした地 域との関係をどのように考え、また具体的な建築に反映しているか という思考の総体は曖昧であると言える。したがって本論では、現 代の建築家の地域集会施設の建築設計論 ${ }^{\text {注 } 6)}$ において、どのように地 域と関わりをもつテーマとしたかといった地域と接点をもつ主題の意味 内容を検討し、さらにその主題が建物のどの場所に具体化されてい るかを領域構成によって整理し、地域と接点をもつ主題との対応を 分析することで、建築家の地域における社会的枠組夕に関する思考 ${ }^{\text {注7 }}$ の一端を明らかにすることを目的とする。この地域における社会的
枠組みに関する思考を具体化する建築家の思考は、建物を地域にお いて意義あるものとする上で重要な内容を含むものと思われる。こ の地域に限定にした社会的枠組みに関する建築家の思考をここでは、 建築家の考える地域性とし、その内容の一端を明らかにする ${ }^{\text {注 } 8)}$

わが国における現代の地域集会施設は、コミュニテイーセターや生涯学習 セりターのように多様な機能を有し、地域コミュテティの形成を目指した複合 施設であるが、その原形は公民館 ${ }^{\text {湆 }}$ にみることができる。わが国に おける公民館は、1947 年には教育基本法が、1949 年には社会教育法 が制定され、社会教育の中心施設として全国の市町村に数多く建設 されてきた ${ }^{10)}$ 。しかし近年の公民館は、1973 年のコミュニテ振興政策 や 1990 年制定の生涯学習振興法などによって ${ }^{\text {注 } 11)}$ 、単に学習や集会 の場としてだけでなく、多様な文化活動や生涯学習の機能を有する 複合施設へ、またまちづくりなど地域のコミュニテイ形成の中心となるコミュ ニテイ施設へと変化していると言える。したがって本論では、このよう な公民館の複合化や時代的な役割の変化などを考慮した上で、公民 館やュミュニテイーセタターといった公立の集会施設を地域集会施設 ${ }^{\text {注 } 2)}$ と捉え、 その建築設計論から建築家が建物と地域との接点をどのように捉え 具体化してきたのかを、通時的傾向とともに分析するものである。

\section{2 既往の研究}

これまで地域集会施設に関する論文では、公民館の機能や利用実 態について建築計画学的に分析したもの ${ }^{\text {注 }}{ }^{12)}$ や、公民館の在り方を 地域計画・都市計画学的に分析したもの ${ }^{\text {注 } 13)}$ 、公民館の内部機能の歷

\footnotetext{
** 島根県庁 修士 (工学)

** 日本国土開発(株)

*** 近畿大学工学部建築学科 講師 · 博士 (工学)

Shimane prefectural government, M.Eng:

JDC Corporation

Assoc. Prof., Faculty of Eng., Dept. of Architecture, Kindai Univ., Dr.Eng.
} 
史的発展について分析したもの ${ }^{\text {注 14) }}$ など公民館に関わる研究を中心 に数多くある。また公共文化施設に関する論文も、建物の形態構成 と使用用途の関係や対応からビルデイダ゙タイプを明らかにしようとした 建築構成論的研究などがある ${ }^{\text {ì }}$ 15) 家の地域集会施設の設計論を題材とし、建築家の設計思想を明らか にする研究は見出し難い。また建築家の言説に関する研究には、建 築家の言説の記述構造を捉えるもの ${ }^{\text {注 16) }}$ や、建築ジャーナリズムにおける 建築家の批評表現を分析するもの ${ }^{\text {注 17) }}$ などがあり、また本論のよう な現代の建築家の複数の設計論に関寸る研究は、戦後「新建築」に 掲載された住宅の設計論の主題を分析したもの ${ }^{\text {注 }}$ (1) などがある。し かし、本論のように現代の建築家の公共文化施設に関する複数の設 計論から、地域と接点をもつ主題を総体的かつ相対的に位置付け、 さらにその具体化の対応を分析することから、建築家の社会的枠組 みに関する思考を具体的な建築空間に投影寸るまでの設計過程を明 らかにするものは見出し難い。また筆者らは既報の研究 ${ }^{\text {注 }}$ か) から、 公共文化施設の設計論の内容には、ビルデイタグタイプ ${ }^{\circ 20)}$ 毎にも特徵が あり、この詳細な分析と比較検討が、今後の公共文化施設の在り方や、 公共性や地域性の議論を進める上で重要な内容を含んでいることを 導いた。このような視点から筆者らは前報 2 編 ${ }^{\text {注 } 21)}$ に続き、公共文 化施設の中でも地域エミニテイの形成を目的とした地域集会施設の設計 論を題材として、建築家の考える地域に関する思考の一端を明らか にしようとするものである。

\section{3 本論の対象資料}

本論では、現代の複数の建築家の設計思想を総体的かつ相対的に 分析する資料として、戦後「新建築」誌 ${ }^{22)}$ に掲載された建築設計 論を対象としている。これまでも、商業ジャーナリズムである戦後「新建築」 誌を資料対象とすることに関しては批判的な意見 ${ }^{\text {注 }}{ }^{23)}$ もるが、筆 者らも十分に検討・検証を重祎、戦後「新建築」誌が長期間（分析 対象期間である 1945 年から現在 2016 年まで）記録的意味合いの強 い専門誌として出版されていること、また建築家の論説を含めた作 品発表誌として広く認知されていることなどから、本論のような複 数の建築家の設計思想を総体的かつ相対的に分析する資料対象とし て「新建築」誌が適していると判断している。また本論では、戦後「新 建築」誌に掲載されている論説のうち、設計された作品（写真や図面） と共に掲載され、建築物の設計における建築家の設計思想が明確に 読夕取れる論説を建築家 ${ }^{\text {注 5) }}$ の建築設計論 ${ }^{\text {注 6) }}$ として取り上げている。
さらに本論では、公共文化施設の建築設計論のうち、建築家の地域 との関わりが読み取れる地域集会施設の建築設計論を分析対象とし ている。現在でも地域集会施設は、公民館だけでも全国に 14,681 館 (平成 23 年 10 月現在) ${ }^{\text {注 } 24)}$ あり数多く存在する。本論ではこうした 地域集会施設の建築設計論のうち、『新建築』誌に掲載された現代の 建築家の建築設計論に限定して分析するものであり、限定した範囲 での考察ではあるが、それらは相対的に現代の建築家の認識の一端 を示し、さらには今後の地域集会施設あるいは公共文化施設の設計 論的視座を得ることができると考えている。

\section{4 本論の概要と分析方法}

そこで本論ではまず、資料とした現代日本の建築家の地域集会施 設に関する論説をすべて通読し内容を十分理解した上で、建築家が 地域と接点をもつ主題 ${ }^{\text {注) }}$ として読み取れる部分を抽出寸る。例え ば図 1 の抽出例 No. 16-1のように「この公民館において、私たちは、 建物と緑の活性化、野生化との直接的なからみあいの中で、総体と しての緑の復権をめざしている。」いいった部分を地域と接点をもつ 主題として抽出することができる。このように抽出した複数の地域 と接点をもつ主題の意味内容を、 $\mathrm{KJ}$ 法 ${ }^{\text {注 } 26)}$ を用いて分類・整理して 関係図を描き意味内容の広がりを提示する。本論では、複数の建築 家の設計思想を総体的かつ相対的に分析する方法として KJ 法をもち いている。抽出した主題をカード化し、カードをもちいて意味の近いも の同士をグルーピングし、それぞれの関係性を検討して意味内容の関係 図を描いている（図 2)。このように KJ 法は、個々の設計論の内容や 文脈などを超えて、複数の建築家の設計思想の枠組みを総体的かつ 相対的に位置付け、意味内容の関係図を描くに適した方法であると 考えている。次に、その地域と接点をもつ主題がどのように具体化 され建物に反映されているかといった部分を抽出する。例えば、抽 出例 No. 16-1 は「表現としては、端的に建物を緑で覆い尽くし、ま わりの緑にとけこませてしまう手法をとっている。」といった部分を、 地域と接点をもつ主題の具体化として読夕取ることができる。この ように抽出した具体化の内容を、地域と接点をもつ主題が、建物の どの場所に反映させているかといった視点で領域的に整理・分析を 行う。さらにこれら地域集会施設の建築設計論における地域と接点 をもつ主題とその具体化との対応関係を通時的傾向とともに考察す ることで、建築家の地域における社会的枠組みに関する思考 ${ }^{\text {注7) }}$ と いった抽象的な概念を具現化する設計思想の一端を明らかにする。

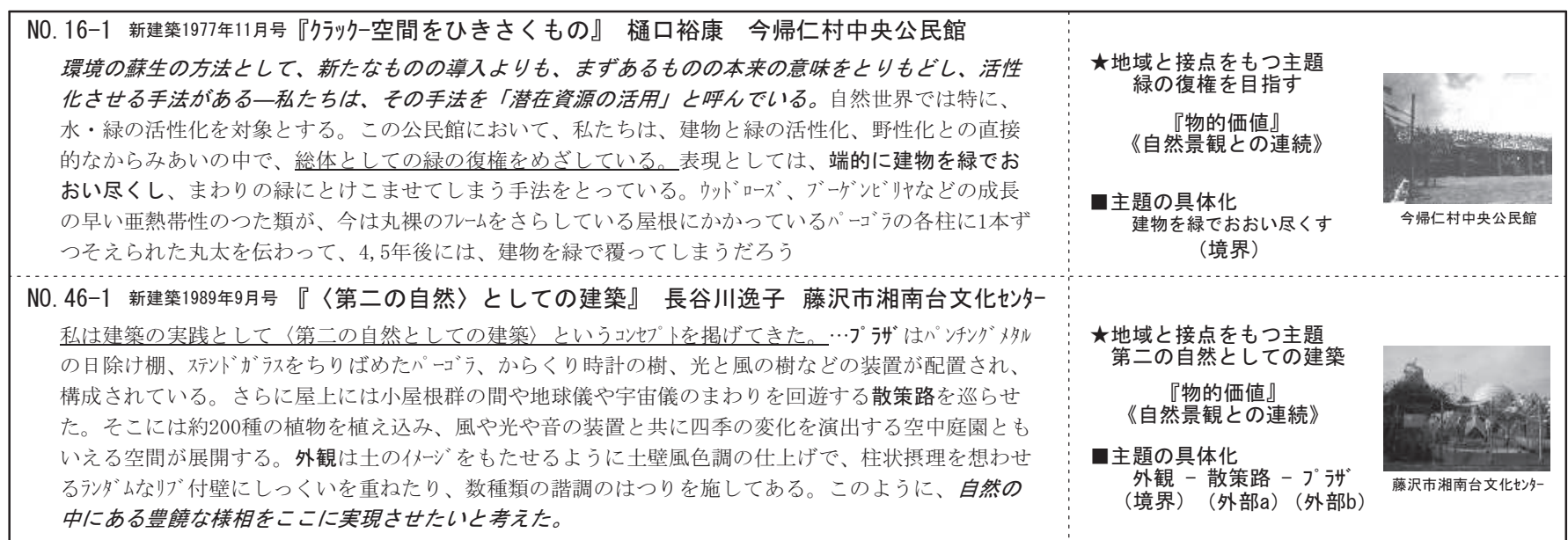

図 1 抽出例 図 1 注)下線部を「地域と接点をもつ主題」、太字を「地域と接点をもつ主題の具体化」として抽出している。 また太字斜体を、「地域と接点をもつ」ことの抽出根拠としている。 


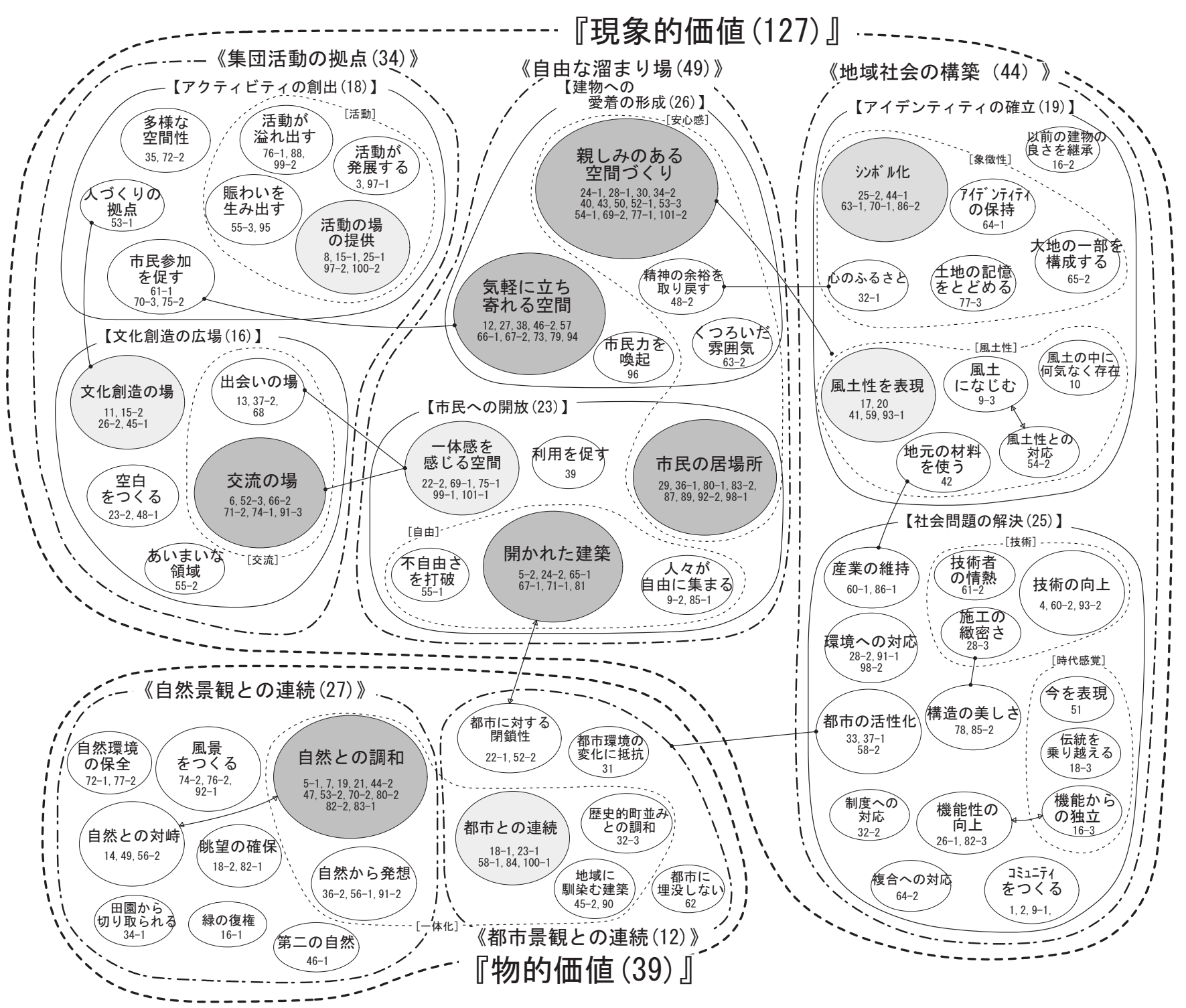

図 2 主題の意味内容の関係図

図 2 注) 各々の意味内容の下の数字は資料番号の通し番号である。また、図中において棒線により示したのは意味内容のつながりの強いもので、 矢印で示したものは意味内容が背反するものである。ひとつの論説より複数の主題が抽出されたものは、さらに添え番号をつけた。

\section{2. 地域と接点をもつ主題}

まず、地域集会施設の建築設計論における地域と接点をもつ主題 の意味内容を $\mathrm{KJ}$ 法を用いて分類・整理すると、いくつかの意味のま とまりをみいだすことができ、それらを図示したのが図 2 である。 その結果まず大枠として、地域集会施設が建つことで生じる活動や 意味等の現象的な側面に着目した内容の『現象的価值』 ${ }^{\text {注 27) }}$ 之、建 物や地域の実体的な側面に着目した内容の『物的価值』で捉えた。 これらは、建物を具現化しまた社会化する建築家の思考を、物（建物） 自体の価値に着目したものか、また物（建物）を背景としたさまざ まな事柄に着目したものかで大きく分類・整理したもので、この前 者を『物的価值』、後者を『現象的価值』とした。つまり『物的』の 対概念として『現象的』を用いている。この『現象的価值』(127/166) と『物的価值』(39/166) の主題の数を比較すると、『現象的価值』 として捉えられる内容が大半を占め、このことから現代の地域集会 施設の設計者は、建物が建てられることで生ずる活動や意味等の現 象的な側面に着目した内容を主題とすることが多いことが分かる。

\section{1 現象的価値}

まず『現象的価值』は《集団活動の拠点》、《自由な溜まり場》、《地 域社会の構築》の 3 つの内容で捉えられた ${ }^{\text {注 }}$ (2) 。このうち《集団活動 の拠点》は【アクテ代テティの創出】と【文化創造の広場】の 2 つの内容 として捉えることができた。この【ア行代ディの創出】は、多様な人

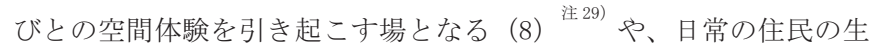
活の発展を期待する（97-2）など様々な活動の場の提供を目指すも の、また、人びとの賑わいを創出する場となる (55-3) や、内部の活 動が外部にあふれ出すことをイメージする (76-1) など [ 活動 ] として 捉えられるものが主に含まれる内容である。この他には、様々な活 動を許容し市民の自主的参加を促す（75-2）ものや、空間に豊かな視 覚的変化をもたせる $(72-2)$ ものなども含まれる。近年では特に、住 民参加のワークショップやまちづくりなどと共に地域の活動の核となる施 設を目指すものも見られる。これに対し【文化創造の広場】は、住 民の多目的なコミュニケーションの場としての機能をもたせる（52-3）や、住 民相互が交流できる場になる (66-2) などのように地域集会施設を住 
民の交流の場となることを目指すもの、住民同士の出会いの場をつ くる（13）など［交流］として捉えられるものと、地域の文化醸成の 場となる（15-2）や、地域の新しい文化拠点となる（45-1）など文化 創造の場としての在り方を模索する内容として捉えられるものがあ

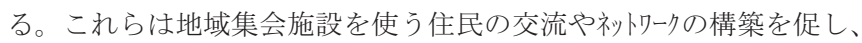
地域における文化創造の拠点となる広場のような空間を目指したも のである。

次に《自由な溜まり場》は【建物への愛着の形成】と【市民への開放】 の 2 つの内容として捉えることができた。まず【建物への愛着の形成】 は、親しみやすい建築として和風の表現を試みた（50）ものや、地域 の人びとに親しまれていた木造校舎の䨌囲気をイメージした（54-1）も のなど、住民にとって親しみのある空間づくりを目指したものや、 通りがかりの人も気軽に出入りできるように配慮した (12) や、誰で も立ち寄ることができる建築を目指した (66-1) などの気軽に立ち寄 れる空間をめざすものなどが主な内容である。この他に、建築が閉 鎖的にならず住民にとってくつろげる空間を目指した (63-2) などが ある。これに対し【市民一の開放】は、市民にとって抵抗感のない 溜り場をつくる (29)、内部が使われていない時でも周りが居場所と なる「街のえんがわ」となることを期待する（87）などの市民の居場 所となろうとするものや、広場をつくることによって開かれた建築 を具現化する (5-2)、地域に開かれた公共の場とする (65-1) など地 域に開かれた建築や人びとが [ 自由 ]に集まることのできる空間を 目指した（85-1）ものなどが主な内容として読み取れる。この他、 建築内部で起こる出来事が互いに分かり合える空間を目指す (22-2) や、利用者相互が気配を感じながら活動できるようにする (99-1) な どの一体感を感じる空間を目指すものも多く見られ、これらはいず れも地域集会施設が住民にとって身近で親しみやすい地域の建築と して認識されることを目指寸主題であると言える。

さらに《地域社会の構築》も、【ア仢“汀仢イの確立】と【社会問題

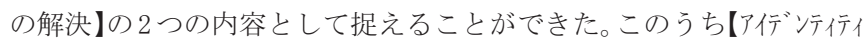
の確立】は、建築にジボ性を与える (44-1) や、外観の表現によっ て市の顔としての在り方を模索する（63-1）など建築のジボ化を目

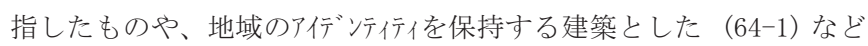
[ 象徵性］として捉えられる内容之、土着的なイメージから建築を思考 した（17）や、その土地の素朴で雄々しい風土性を感じさせようとし た（59）などの風土性を表現するもの、建築を風土的に関係付けて風 土になじむ建築を目指した（9-3）などの［風土性］として捉えられ る内容が主である。これに対し【社会問題の解決】は、日本では前 例の少ない HP シェルの屋根をかける（4）や、外壁の打ち放しコンクリートの 美しさに気を使った（28-3）などの［技術］の向上を目指したものや、 様式や伝統を乗り越え現代の建築を目指寸 (18-3)、現代の生活や行 動に適した建築の在り方を模索した（51）などの［時代感覚］を表現 するものも含むが、地域のまちづくりの一環として建築する (37-1) や、積雪への対策から屋根の形状を考える (28-2)、まちの主たる産 業である林業を守るため木材を積極的に利用する (60-1) など様々な 内容を含んでいる。これらはいずれも地域の象徴としての建築の在 り方や現代の社会問題への対応し、地域住民の共同体意識や帰属意 識を構築したり再認識させたりすることを主題とするものである。

以上関係図から、地域集会施設が建てられることで生じる活動や 意味に着目した主題 (『現象的価値』) は、《自由な溜まり場》(49/127)、
《地域社会の構築》(44/127)、《集団活動の拠点》(34/127) の順で数 が多く、中でも【建物への愛着の形成】や【市民への開放】といっ た内容で捉えられる《自由な溜まり場》が最も多いことがわかる。 また、この《自由な溜まり場》として捉えられる内容は、他の意味 内容との関連も多いことが読み取れることから、現代の地域集会施 設の建築設計論において建築家は、建物に市民が自由に集まり活発 な活動を生み出し、地域のコミュニテ形成のきっかけをつくるような役 割をもつ場所とすることを、地域と接点をもつ主題の中心 ${ }^{\text {注 }}$ (0) $と$ 考 えていることを示している。

\section{2 物的価値}

次に『物的価值』は《自然景観との連続》と《都市環境との連続》の $2 つ$ の内容で捉えられた。このうち《自然景観との連続》は、背後に存 在する松山と建築の融合を目指した (7)、周辺に広がる沼の水面に馴 染ませた (82-2) などの自然との調和を目指寸ものや、周辺の自然景 観のイメージから建築の形を発想した（36-2)、海とつながる風景をつく ろうとした（76-2)、周辺の自然と対峙する建築の在り方を模索した （49）など、建築を囲う自然環境と一体的に思考することによって周 辺環境との連続性を生み出し、地域との繋がりを表現しようとする ものである。中にはあえて自然と対峙させることで建築の存在感を 周囲に対して発信しようと寸るものも見られた。これに対し《都市 景観との連続》は、周辺の建築や街並みとの連続性を確保する $(18-1)$ や、混みあった街区、周辺に対してできるだけジプルな秩序を形成す る (58-1) などの都市との連続として捉えられるものや、瀬戸内海の 景観の構造を抽象化する (90)、古い町のイメジと䨌囲気を建築に取り 込む (32-3)、前面の幹線道路に対する閉鎖性を獲得する (52-2) など、 建築を囲う都市環境と一体的に思考することによって周辺の都市環 境との連続性を生み出し、地域との繋がりを主題とするものである。 これら建物や地域の実体的な側面に着目した『物的価値』として捉 えられる内容で《自然景観との連続》 $(27 / 39)$ と《都市景観との連続》 (12/39) の数を比較すると、《自然景観との連続》が比較的多いこと がわかる。この『物的価値』(39/166) に関する内容は、前節の『現 象的価値』(127/166) に比べて数が少なく、地域集会施設の設計論 の主題の中心的な内容とは言えないが、このことは現代の地域集会 施設を設計する建築家が、建物や地域の物的価值に着目して地域と 接点もつ主題とする場合は、都市景観よりも自然景観との連続性を 意図寸ることで、より有機的で豊かな文化芸術活動の場を生み出そ うとしていると考えることができる。

\section{3 地域と接点をもつ主題の通時的傾向}

次に、表 1 のように地域集会施設の建築設計論における地域との接 点をもつ主題を通時的に考察する。まず表 1 及び表 3 より 1950 年代 (3/166) から 1960 年代 $(5 / 166)$ の主題数は少なく、このことからも、 戦後建築家が地域集会施設を設計し、その建物や設計論が建築雑誌 で発表されるようになったのは主に 1970 年代（14/166）以降である ことが分かる。また表 1 より、地域集会施設の建築設計論の主題数 は 1980 年代以降に飛躍的に多くなり 1980 年代 $(47 / 166) 、 1990$ 年代 (55/166)、2000 年以降 $(42 / 166)$ と 1990 年代が最も多いことがわかる。 このことは、1980 年代後半から 1990 年代前半にかけたいわゆるバブル 経済の好景気の時に多くの地域集会施設が建設され、この時期に建 築家も多くの地域集会施設の設計に携わったと考えることもできる が、その後の不況と言われる経済状況や阪神淡路大震災、東日本大 
震災などが起こった社会状況においても建築家による地域集会施設 の建築設計論は多く掲載・発表されており、1980 年代以降の地域集 会施設は、社会状況の変化に柔軟に対応できる最も身近な地域施設 として捉えられ、建築家もそれに同調し取り組んでいると考えるこ とができる。次にまず『現象的価值』の通時的傾向に着目すると、《自 由な溜まり場》の【建物への愛着の形成】が 1980 年代 $(9 / 47)$ か ら 1990 年代 $(11 / 55)$ にかけて多いことが分かる。1980年代から 1990 年 代は、1960 年代のいわゆる高度経済成長以降、地域住民の日常生活 に必要な数の建物が建てられ、物的な充足から（文化や豊かさといっ た）精神的な充足へ」といった一般的な議論が進む中で、地域集会 施設が、公民館のような単独の集会機能をもつ建物から、様々な機 能をもつ複合的で大規模なコミュテイ施設へと大きく変化した時期であ る。したがって 1980 年代から 1990 年代までの地域集会施設を設計 する建築家は、それまでの画一化したイメージから脱却し、より親しみ や寸く透明性の高いデザインで建物への愛着を生み出し、このことで 施設機能の複合化や大規模化といった複雑な様相に対応していたと 考えらえる。またこれに対し 2000 年以降は、《自由な溜まり場》の【建

\section{表 1 地域と接点をもつ主題の通時的傾向}

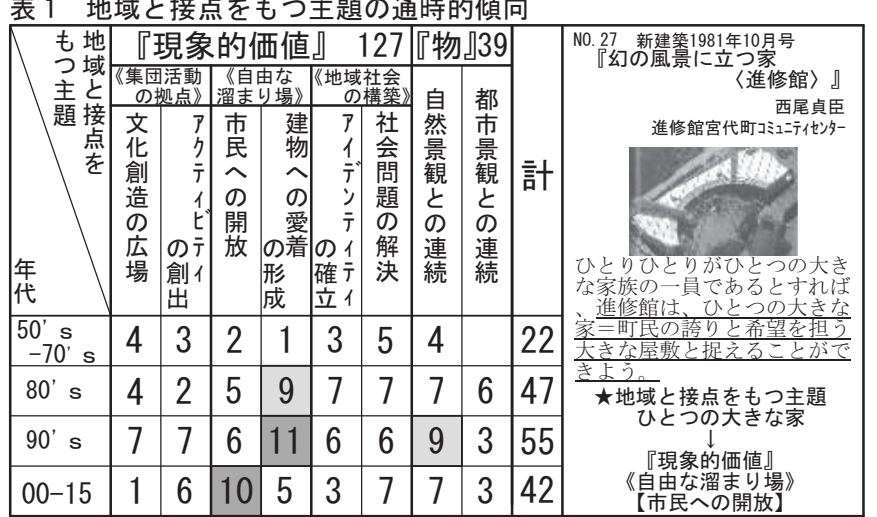

物への愛着の形成】 $(5 / 42)$ よりも【市民一の開放】（10/42）の数が 多くなっている。このような 2000 年以降の傾向は、1995 年の阪神淡 路大震災以降から盛んに行われるようになった「住民参加型」によ る公共施設の建設過程や地域施設の在り方の再考に関寸る議論など によって、地域集会施設は、地域におけるコミュニテ施設としての役割 が強く求められるようになったと考えられる。このような社会状況 を踏まえて、地域集会施設を設計する建築家は、2000 年頃を境にして、 より多くの地域住民に施設を開放し積極的な利用を促すことで地域コ ミュニティの再構築を目指寸思考に推移したと考えられる。またこれらに 対し『物的価值』は全体の数は多くはないが、相対的に《都市景観 との連続》(12/39) より《自然景観との連続》(27/39) が多く、特 に 1990 年代の 《自然景観との連続》(9/55) が比較的多い傾向を読 み取ることができる。このことは地域集会施設を設計する建築家は、 周辺の都市環境との連続性よりは自然環境と一体となった有機的な 建築の在り方を思考する傾向にあり、それは近年まで続いていると 考えられる。

\section{3. 地域と接点をもつ主題の具体化}

ここでは、抽出した地域集会施設の建築設計論における地域と接 点をもつ主題の具体化について検討する。まず、すべての地域と接 点をもつ主題の具体化の内容を通覧し領域的にいくつかのカラゴリーに 分類・整理した（表 2)。全体を敷地内と敷地外に分け、敷地内をさ らに内部、境界、外部に分けた。このうち内部とは、集会室や教室 などがある主室部と、エントランイや比一、廊下などの動線部を含む市民 が利用可能な建物の内部空間である。また境界とは、建物の外形、ヴ オリューム、外壁、屋根など主に建物の外観を指寸。さらに外部は、広場 や中庭など配置による外部（a）とピ呋や屋上庭園など建築化された 外部 (b) を含む外部空間である。また敷地外は、公園や住宅地など

表 2 地域と接点をもつ主題の具体化の領域的広がり

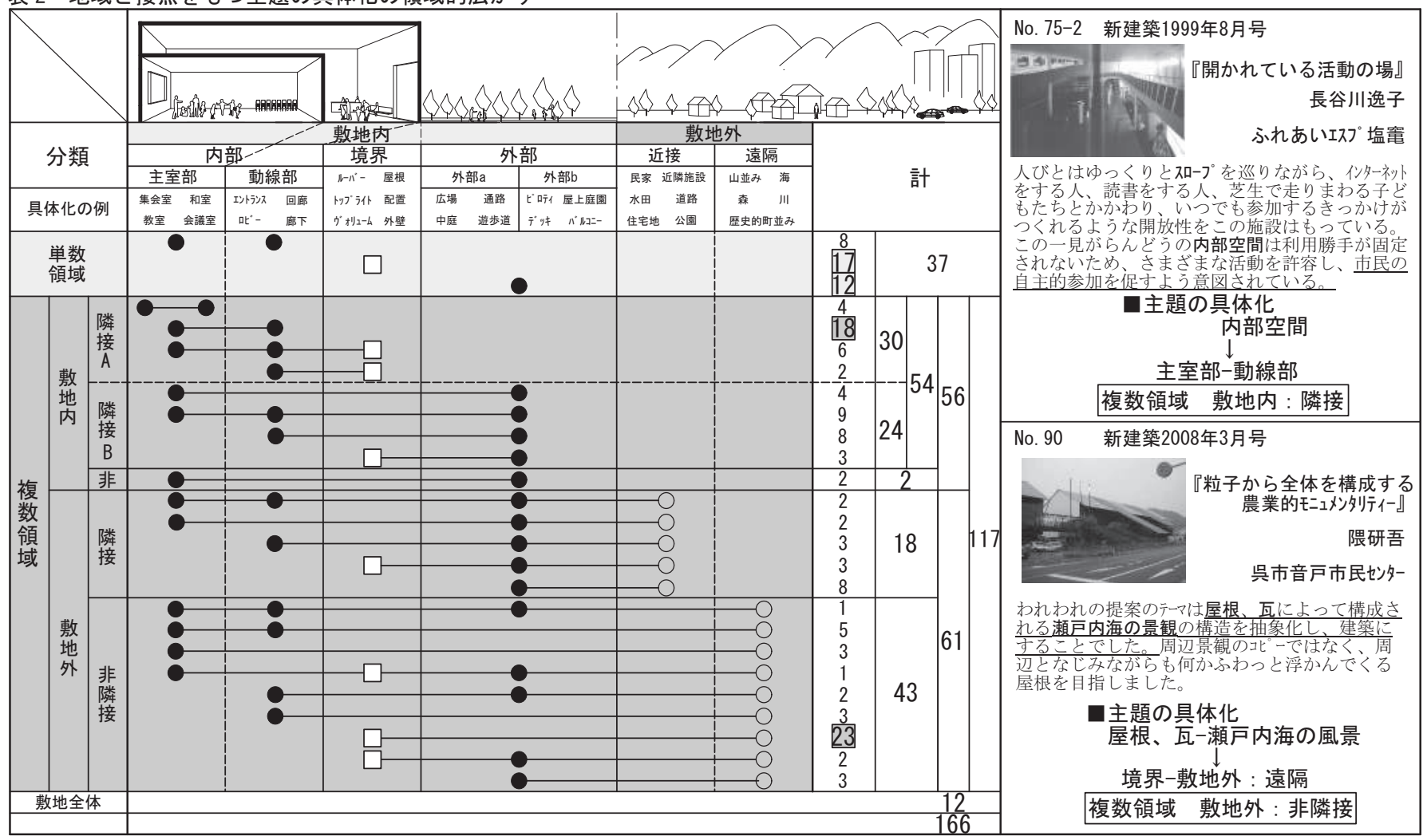


の敷地と隣接関係にあるもの近接と、山並みや川、湖といった敷地 から離れた場所にある遠隔に分けた。また、上記のような領域的な 分類が出来ないものを敷地全体とした

また主題は、内部、境界、外部、といった単数の領域内で具体化 されるだけでなく、複数の領域の関係性によって具体化されるもの も多くみられた。そこでそれらを具体化の領域的広がりとして捉え、 複数の領域と関係をもつものを線で結んだ。さらに具体化の領域的 広がりを、他の領域と関係をもたない単数領域と、複数の領域と関 係をもつ複数領域の $2 つ に$ 分類・整理した（表 2)。また具体化の領 域的広がりにおける複数領域を、敷地内の関係による敷地内之、敷 地外と関係をもつ敷地外に分け、さらにそれぞれ領域間の関係性を 考察するために、領域同士が連続した関係にあるものを隣接、不連 続な関係にあるものを非隣接として分類した。この隣接関係にある ものとは、主に人間の移動が可能な建築空間の連なりを示すもので あり、これに対し非隣接関係にあるものとは、主に領域の隣接関係 を超えて眺望や人間の視覚的つながりに着目したものとして捉える ことができる。さらに、敷地内の隣接関係にあるものを、外部との
関係を持たず、建物内の領域のみの関係性による隣接 A と、外部と の関係性をもつ隣接 B として分類した。また内部の主室部には、室 同士の関係によって具体化するものも見られたので、これらを隣接 $\mathrm{A}$ に分類した。

これらをもとに地域集会施設の建築設計論における具体化の領域 的広がりを表 2 のように整理すると、地域集会施設の地域との接点 をもつ主題の具体化は、単数領域 $(37 / 166)^{\text {注 } 31)}$ と複数領域 $(117 / 166)$ では、複数領域の方が多いことが分かる。これは地域集会施設の建 築設計論において建築家が地域との関わりを具現化しょうとする際 には、複数の領域間の関係性によって表現しようとする傾向にある ことを示しており、このことは既報の研究 ${ }^{\text {注 }}{ }^{11}$ と比較しても公共文 化施設の建築設計論の中で地域集会施設のもつ特有な傾向であると 言える。また複数領域に着目寸ると、敷地内の領域間の関係性によ るもの (56/117) と敷地外の領域との関係性によるもの $(61 / 117)$ では、同程度の数を読み取ることができる。このことは、地域集会 施設の建築設計論における地域と接点をもつ主題の具体化では、敷 地内の領域同士の関係性だけでなく、敷地外の領域を含む空間の連

表 3 資料リス卜と地域と接点をもつ主題の具体化の領域的広がり

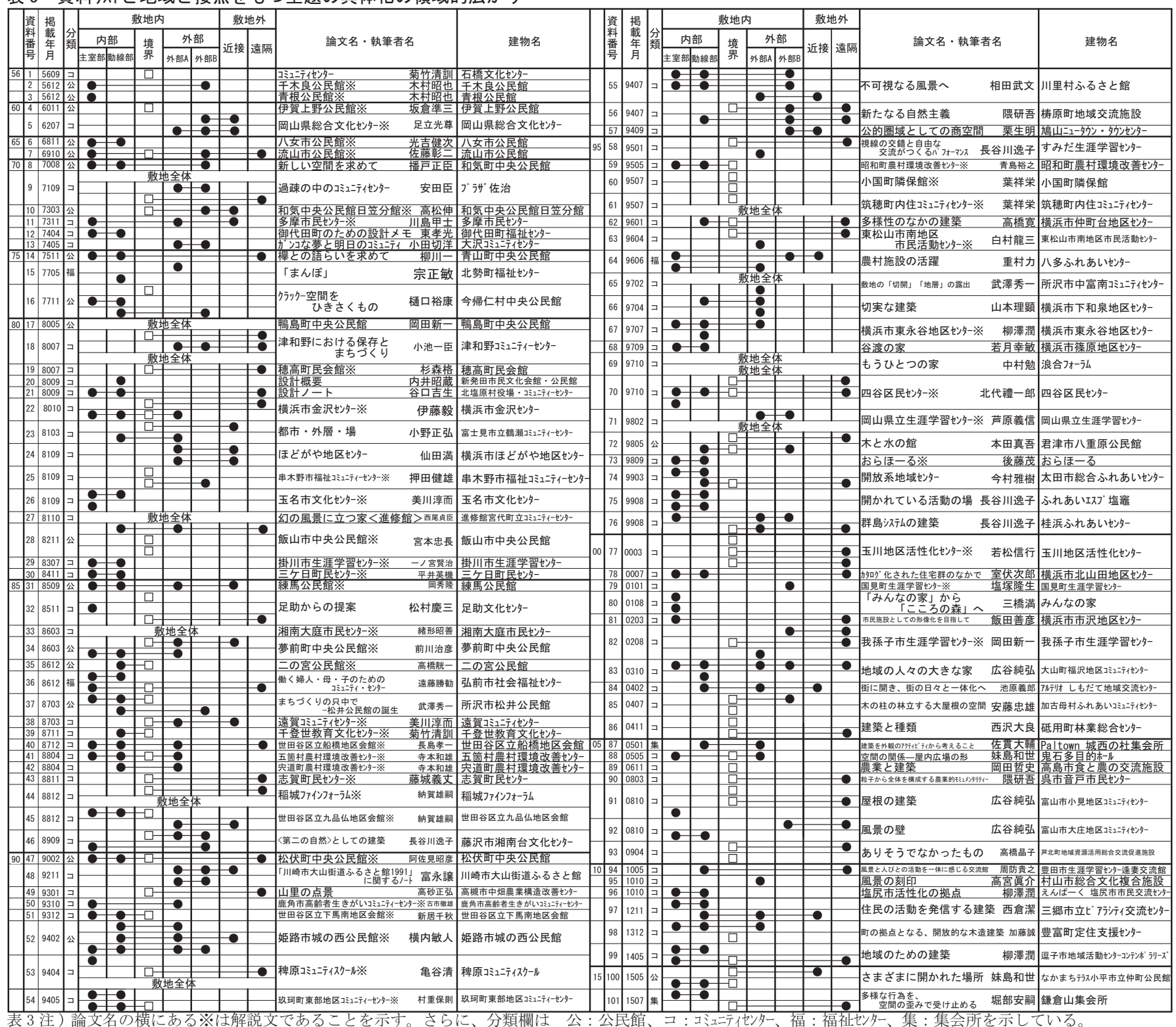


続性も重視されていると言える。さらに敷地内の領域間の関係性に よるものは、ほとんどが隣接 $(54 / 56)$ 関係によるものであることが 分かる。また外部空間を含まない隣接 $\mathrm{A}(30 / 54)$ と、外部空間を含む 隣接 B (24/54) でも同程度の数を読み取ることができるが、その内容 を細かく見ると、主室部と動線部（18/30）の関係性によって表現す るものが多いことが分かる。またここで単数領域に着目すると、主 室部や動線部など内部空間の特定な場所 (8/37) で具体化するもの は少なく、ほとんどが建築の外観や外形などの境界 $(17 / 37)$ や広場 や中庭などの外部空間 $(12 / 37)$ であることが分かる。またこれらに 対し敷地外と関係をもつ具体化は、非隣接 $(43 / 61)$ 関係によるもの が多く、特に敷地外・遠隔の環境要素と建築の外観や外形などの境

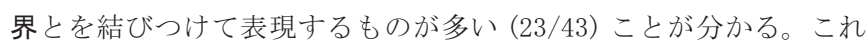
らのことから、まず地域集会施設の建築設計論において建築家が敷 地内で地域と接点をもつ主題を具体化しょうとする場合は、室同士、 室と廊下、外部と内部、など隣接した空間の相対的な関係や連続性 によって具体化するか、建築の外観か外部空間で具体化することが 多いことが分かる。これに対し地域集会施設の建築設計論において 建築家が敷地外との環境要素と結びつけて具体化しようとする場合 は、建物からの眺望より、敷地外の環境要素やイメージを建物の外観に 反映させて表現することが多いことを示している。

続いて地域集会施設の建築設計論における具体化の領域的広がり の通時的傾向を分析した（表 4)。この結果、1950 年代から 1970 年 代までは明確な傾向は読み取ることが出来ないが、相対的に複数領 域の敷地内：隣接 $(7 / 21)$ が多いことが分かる。この傾向は 1980 年 以降も続き、1980 年代（18/42）1990 年代（19/49）における地域集 会施設の建築設計論の地域と接点をもつ主題の具体化は、複数領域 の敷地内：隣接が最も多いと言える。しかし同時に複数領域の敷地 外：非隣接も 1980 年代 $(11 / 42)$ と 1990 年代 $(13 / 49)$ と比較的多 く、さらに 2000 年代以降は、複数領域の敷地外: 非隣接（16/42）が、 敷地内: 隣接 $(10 / 42)$ の数を上まっていることが分かる。このことは、 地域集会施設を設計する建築家の地域と接点をもつ主題の具体化は、 2000 年頃を境として、隣接する領域間の相対的な関倸性や連続性な ど建築の空間構成による具体化から、地域を象徵する敷地周辺の環 境要素やイメジを建物の外観に表現するような建築の外形表現による 具体化に、その中心が推移したことを示している。

\section{4. 地域と接点をもつ主題とその具体化の対応}

前章までは、地域集会施設の建築設計論における地域と接点をも つ主題とその具体化の内容について別々に検討してきたが、本章で はその対応について検討する。まず、地域集会施設の建築設計論に おける主題の大枠として捉えた『現象的価值』、『物的価值』と、主 題の具体化の大枠として捉えた領域的広がりにおける単数領域、複 数領域との対応関係を検討した（表 5)。その結果まず、主題の『現 象的価值』と具体化の領域的広がりにおける複数領域との対応 (81/166) が最も多いことが分かる。また特にその内容を細かく見る と、『現象的価值』は複数領域の敷地内：隣接 $(53 / 81)$ が多いことが 分かる。このことから、地域集会施設の設計において建築家は、建 物を建てることによって生ずる活動や意味など現象的価值に基づい た主題を、敷地内における隣接した空間同士の相対関係や領域間の 連続性によって具現化することが多いことが分かる。このことは地
表 4 主題の具体化の領域的広がりの通時的傾向

\begin{tabular}{|c|c|c|c|c|c|c|c|c|c|c|}
\hline & & & & & & 数令 & 頁域 & 117 & & №. 74-1 新建築1999年3月号 \\
\hline & & & & & & 也内 & 敷士 & 也外 & & 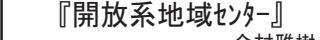 \\
\hline & & 部 & & & & 非 & & & 計 & 太田市総合ふれ念森雅尌 \\
\hline & 主 & $\begin{array}{l}\text { 動 } \\
\text { 線 }\end{array}$ & 喟 & 部 & 接 & $\begin{array}{l}\text { 隣 } \\
\text { 接 }\end{array}$ & 接 & $\begin{array}{l}\text { 隣 } \\
\text { 接 }\end{array}$ & & 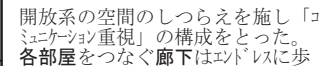 \\
\hline $\begin{array}{ll}50, & s \\
-70^{\prime} s & \end{array}$ & & 1 & 3 & 3 & 7 & & 4 & 3 & 21 & 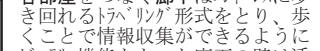 \\
\hline $80^{\prime} \mathrm{s}$ & & 1 & 4 & & 18 & 1 & 7 & 11 & 42 & 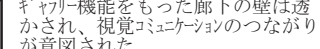 \\
\hline 's & 1 & 1 & 3 & 6 & 19 & 1 & 5 & 13 & 49 & 主題の具体化 \\
\hline $\begin{array}{l}s \\
-15\end{array}$ & 3 & 1 & 7 & 3 & 10 & & 2 & 16 & 42 & 複数領域 敷地内: 隣接 \\
\hline
\end{tabular}

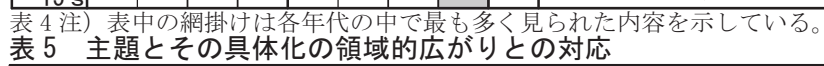

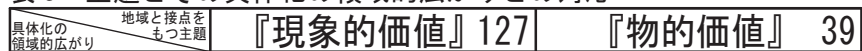

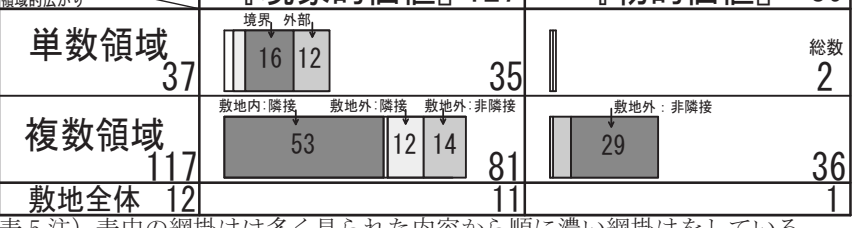

表 6 主題とその具体化の領域的広がりとの対応の詳細

\begin{tabular}{|c|c|c|c|c|c|c|c|c|c|c|c|}
\hline $\begin{array}{l} \\
\text { 領具 } \\
\text { 体 } \\
\text { 的化 } \\
\text { 広の } \\
\text { 市 } \\
\text { り } \\
\end{array}$ & も & 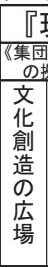 & 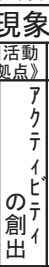 & 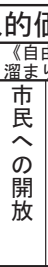 & 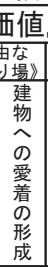 & 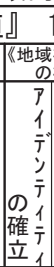 & 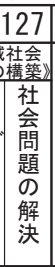 & 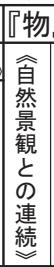 & 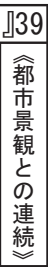 & 計 & \multirow{3}{*}{ 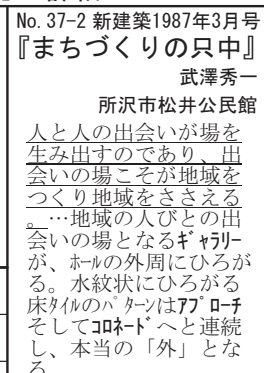 } \\
\hline 単 & 内主室 & 1 & 1 & 1 & & & & 1 & & 4 & \\
\hline 数 & 動線 & 1 & & 1 & 1 & 1 & & $(2)$ & & 4 & \\
\hline 域 & 境界 & & 2 & 1 & 1 & 1 & 11 & 1 & & 17 & $\begin{array}{l}\text { る。 } \\
\text { 太地域と接点をもつ主是 }\end{array}$ \\
\hline 37 & 外部 & $2 \mathfrak{1}$ & 2 & 2 & 3 & 1 & 2 & & & 12 & \\
\hline 复敷 & 隣接 & 0 & 10 & 13 & 8 & 6 & 7 & 1 & & 54 & \\
\hline 肴内 & 非隣接 & & & & 2 & & & & & 2 & \\
\hline 或 & 隣接 & 2 & 2 & 2 & 4 & 2 & 3 & 2 & 4 & 18 & \\
\hline 7外 & 非隣接 & & 1 & 1 & 4 & 7 & 1 & 21 & 8 & & \\
\hline & 它全体 & & & & & & & & & & 敷地内：隣接 \\
\hline
\end{tabular}

表 6 注）表中の濃い網掛けは傾向が影著に表れている部分、薄い網掛けは傾向 表 7 主題とその具体化の領域的広がりとの䇃応の通時的傾向

\begin{tabular}{|c|c|c|c|c|c|c|c|c|c|c|c|}
\hline \multirow{5}{*}{\multicolumn{2}{|c|}{ 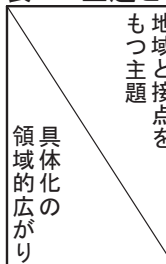 }} & \multirow{5}{*}{\multicolumn{2}{|c|}{ 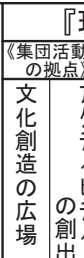 }} & \multicolumn{4}{|c|}{ 現象的価値』 } & \multicolumn{2}{|c|}{ 『物的』 } & \multirow{2}{*}{\multicolumn{2}{|c|}{$\begin{array}{c}\text { No. 82-1 新建築2002年8月号 } \\
\text { 『我孫子市 } \\
\text { 生涯学習センタ-』 }\end{array}$}} \\
\hline & & & & & 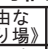 & & 䄍堬 & 自 & 鄛 & & \\
\hline & & & & 市 & \begin{tabular}{|l|} 
建 \\
物
\end{tabular} & & & 然 & 留 & & 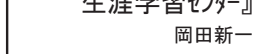 \\
\hline & & & & $\hat{\omega}$ & $\hat{\Phi}$ & & $\begin{array}{l}\text { 減 } \\
\text { 遉 }\end{array}$ & 霍 & 霍 & 計 & 我孫子市生涯学習也歼 \\
\hline & & & & 開 & 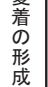 & 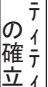 & $\begin{array}{c}\text { 分 } \\
\text { 解 }\end{array}$ & $\begin{array}{l}\text { の } \\
\text { 連 } \\
\text { 筅 }\end{array}$ & $\begin{array}{l}\text { の } \\
\text { 連 } \\
\text { 続 }\end{array}$ & & 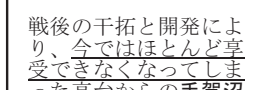 \\
\hline \multirow{4}{*}{$\begin{array}{l}\text { 単 } \\
\text { 数 } \\
\text { 領 } \\
\text { 域 }\end{array}$} & $\begin{array}{c}50^{\prime} \mathrm{s} \\
-70^{\prime} \mathrm{s}\end{array}$ & & & & & & 2 & 1 & & \multirow{6}{*}{\multicolumn{2}{|c|}{ 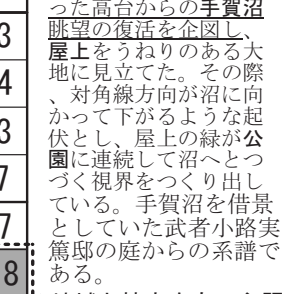 }} \\
\hline & $80^{\prime} \mathrm{s}$ & & 1 & & & 1 & 2 & & & & \\
\hline & $90^{\prime} \mathrm{s}$ & & 1 & & & ? & 2 & & & & \\
\hline & $00-15$ & & & 1 & 1 & & 5 & & & & \\
\hline & 50 & 1 & 2 & & 1 & 1 & 2 & & & & \\
\hline & $80^{\prime} \mathrm{s}$ & 4 & 1 & 4 & 2 & 3 & 3 & 1 & & & \\
\hline & $90^{\prime} \mathrm{s}$ & 4 & 4 & 3 & 4 & 2 & 2 & & & 19 & \multirow{4}{*}{ 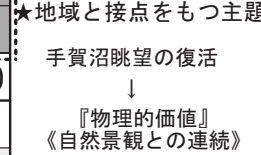 } \\
\hline & $00-15$ & & $3:$ & 6 & 1 & & & & & 10 & \\
\hline \multirow{3}{*}{ 領域敷 } & & & & & & & & & & 10 & \\
\hline & $\begin{array}{r}-70^{\circ} \mathrm{s} \\
\end{array}$ & & & & & 1 & & 2 & & & \\
\hline & $80^{\prime} \mathrm{s}$ & & & & 2 & 1 & & 4 & 4 & 11 & \multirow{4}{*}{\begin{tabular}{|c} 
主題の具体化 \\
屋上 手賀沼、公園 \\
$\downarrow$ \\
$\downarrow$ \\
複数領域
\end{tabular}} \\
\hline & $90^{\prime} \mathrm{s}$ & & & & & 2 & & 9 & 2 & 13 & \\
\hline $7 / 4$ & $00-15$ & & 1 & 1 & 2 & 3 & & 6 & 2 & 6 & \\
\hline & 3全体 & & & & & & & & & 2 & \\
\hline
\end{tabular}

表 7 注）表中の濃い網掛けは傾向が顕著に表れている部分、薄い網掛けは傾向 が読み取れる部分を示している。表中の(1)(2)(3)パターンを示している。 
域集会施設の建築設計論において顕著な傾向を示しており、建築家 の地域と接点をもつ主題とその具体化の対応における中心的内容で あると言える。また『現象的価值』は、単数領域の境界 $(16 / 35)$ と 外部 $(12 / 35)$ 、複数領域の敷地外：非隣接 $(14 / 81)$ と敷地外：隣接 (12/81) との対応が多いことが分かる。これらに対し『物的価值』 は、複数領域の敷地外：非隣接（29/36） との対応が比較的多く、単 数領域（2/166）によって具体化することはほとんどないことが読み 取れる。これらのことから、地域集会施設の設計において建築家は、 建物や地域の実体的な側面に着目した物的価値を主題とする場合は、 周辺の自然や都市といった敷地外の環境要素やイメージと建物と結びっ けるような視覚的つながりによって具現化することが多く、外観や 広場など特定の部分に象徴的に表現されることは少ないことが分か る。

次に、表 6 のように地域と接点をもつ主題とその具体化の対応を 細かくみると、大きく 3 つのパターンを読み取ることができた。まず(1現 象的価值』の内容では、《集団活動の拠点》の【アクテイビティの創出】や、 《自由な溜まり場》の【市民一の開放】といった主題が、具体化の領 域的広がりにおける複数領域の敷地内：隣接との対応が多いことが 分かる。このことは地域集会施設の設計において建築家は、住民の 積極的な活動を促したり住民が自由に利用できる開かれた建築を目 指したりするような、地域集会施設に求められる住民同士のコミュニケーシ ョンの場としての在り方を主題とする際には、内部の空間同士の相対 関係や内部と外部の連続性など空間的つながりによって具体化しよ うとする傾向にあることを示している。次に、(2)『現象的価值』の 《地域社会の構築》の【社会問題の解決】といった主題は、具体化の 領域的広がりにおける単数領域の境界との対応が多い。このことは 地域集会施設の建築設計論において建築家は、立地する地域の気候 · 風土への対応や産業・技術力の向上など、地域社会の構築に必要な 社会問題への対応を主題と寸る場合、建築のフアサードや外形、外壁な どの外観に象徵的に表現しょうと寸る傾向にあることを示している。 これらに対し(3)『物的価值』の内容では《自然景観との連続》が、 具体化の領域的広がりにおける複数領域の敷地外：非隣接との対応 が多いことが分かる。このことは建築家が、建物と自然景観との連 続性を主題とする場合は、敷地周辺の環境要素やイメージを建築のファ开一 ドなどの外観に結びつけるような視覚的つながりによって具体化さ れることが多いことを示している。この傾向は地域集会施設の建築 設計論の地域と接点をもつ主題と具体化の対応において最も数が多 く顕著な傾向を示寸ものではあるが、他のビ恼゙イン゙タイ゚ 注21) く見られ、公共文化施設の建築設計論の特徴であると言える。

さらに、表 7 のように主題とその具体化の対応の通時的傾向を(1)、 (2)、(3)に着目して考察すると、まず1)（主題の『現象的価值』と主 題の具体化の複数領域の敷地内：隣接との対応）は、1980 年代か ら 1990 年代までは《集団活動の拠点》や《自由な溜まり場》それぞ れに分散した傾向にあるが、2000 年代以降は《自由な溜まり場》の 【市民一の開放】に比較的集中した傾向を読み取ることができる。ま た(2) (主題の『現象的価值』《地域社会の構築》と主題の具体化の単 数領域の境界との対応）も、2000 年頃を境に【社会問題の解決】の 増加傾向を読み取ることができる。さらにこれに対して(3)（主題の 『物的価值』と主題の具体化の複数領域の敷地外：非隣接との対応） は、1990 年代に最も集中した傾向を読み取ることができるが、2000 年
代以降減少傾向にあることが読み取れる。これらのことから現代の 地域集会施設を設計する建築家は、2000 年頃までは、多様な芸術文化・ 交流活動が可能な集会施設として複合化する機能や施設の大規模化 に対応し、隣接する領域間の相対的な関係性や連続性など建築の空 間構成によって地域との接点を表現するなど、地域性の多様な表現 の可能性を模索していたが、2000 年以降は、地域施設そのもの在り 方を再考するような社会的状況に対応し、地域のコミュニテ形成の拠点 施設としてより開放的なイメージを建物の外観に表現するといった建築 の外形表現によって地域性を表現する思考に推移していることを示 している。しかし、これら現代の地域集会施設の建築設計論におけ る地域と接点をもつ主題とその具体化は、この 3 つのパターンの内に形 式化した傾向を読み取ることができ、さらにこの傾向は 2000 年頃を 境として、地域集会施設における建築家の地域性の表現が、空間構 成の修辞的操作によるものから、建物の外形のイイージ表現へと推移し 偏りを強めていることを示すものと考えことができる。このような 地域集会施設の建築設計論における傾向は、近年の建築家の考える 地域性に関する思考の偏りを示すものであり、この偏りを見直すこ とが今後の地域集会施設の設計や新しい公共文化施設の計画に必要 であると考えられる。

\section{5. 結}

本論は、建築家によって著された戦後の地域集会施設の建築設計 論の中から、地域と接点をもつ主題とその具体化を検討することで、 現代日本の建築家が考える建築の地域性の意味の広がりを示した。 そのためにまず、ここで取り上げた資料において抽出した地域と接 点をもつ主題の意味内容を KJ 法をもとに分析を行い、建物が建てら れることによって生じる活動や意味など現象的な側面に着目した内 容と、建物や周辺の環境の実体的側面に着目した内容として大枠を 捉え関係図を示した。そこでは現象的な内容が多く、特に建物への 愛着の形成や市民一の開放といった自由な溜まり場を形成しようと する内容が地域と接点をもつ主題の中心にあることを示した。また その主題の通時的傾向から、2000 年頃を境に住民にとって親しみや すく、気軽に訪れることのできる地域集会施設の在り方を模索する 内容から、地域に開かれ多くの人びとの積極的な利用を促す内容に 推移したといった、建築家の考える地域集会施設の公共文化施設之 しての認識の変化を示した。次に、抽出した地域と接点をもつ主題 の具体化を領域的に整理し、その広がりとして、他の領域と関係を もたないもの (単数領域)、複数の領域と関係をもつもの（複数領域） の 2 つまとまりとして大枠を捉えた。また、複数の領域と関係を もつもの（複数領域）は、敷地内の関係によるもの（敷地内）之敷 地外と関係をもつもの（敷地外）で捉え、さらに空間的つながりを 示寸隣接と、視覚的なつながりを示寸非隣接に分けて分析を行った。 この結果、地域集会施設の建築設計論では、敷地内における特定の 場所によって具体化することよりも、複数領域の特に隣接の関係性 によって地域に関わる主題を具体化することが多いこと。またその 中でも、敷地内の空間的つながりや敷地外の環境要素と建物の外観 をむすびつけるような視覚的つながりによる具体化が多いことが分 かった。また通時的な傾向から、地域集会施設の建築設計論におけ る地域と接点をもつ主題の具体化も、2000 年頃を境に、隣接する領 域間の相対的な関係性や連続性といった建築の空間構成による具体 
化から、地域を象徵する敷地周辺の環境要素やイメージを建物の外観に 表現するといった外形表現による具体化に変化したことを明らかに した。

最後に、地域と接点をもつ主題とその具体化の対応から、(1) アクテ化デイの創出や市民への開放に関する主題は、内部空間同士の関 係性や内部と外部の連続性など敷地内の空間的つながりによって具 体化されることが多いこと。(2)現代の地域における社会問題への対 応に関する主題は、建築のファサードや外形などの外観によって表現さ れる傾向にあること。(3)敷地周辺の自然や都市との景観的連続性を 主題と寸るものは、敷地周辺の環境要素と建築の外観との視覚的関

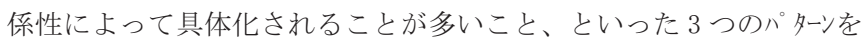
導いた。またそれらの通時的傾向から、現代の地域集会施設を設計 する建築家は、2000 年頃までは、多様な芸術文化・交流活動が可能 な集会施設として複合化する機能や施設の大規模化に対応し、隣接 する領域間の相対的な関係性や連続性など建築の空間構成によって 地域との接点を具体化することが多かったが、2000 年以降は、地域 施設そのもの在り方を再考するような社会的状況に対応し、地域の ミュニティ形成の拠点施設としてより開放的なイメージを建物の外観に具体 化するなど建築の外形表現によって地域との接点とする思考に変化 していると言える。しかし、これら現代の地域集会施設の建築設計 論における地域と接点をもつ主題とその具体化は、この 3 つのパタ-ン の内に形式化した傾向を読み取ることができ、さらにこの傾向は 2000 年頃を境として、地域集会施設における地域性の表現が、空間 構成の修辞的操作によるものから、建物の外形のイメージ表現へと推移 し偏りを強めていることを示すものと考えることができる。このよ うな傾向を見直すことが今後の地域集会施設の設計や新しい公共文 化施設の計画に必要であると考えられる。これらの結果は近年の建 築家が、新しい地域性や公共性に対する考えを実現するきっかけと して地域集会施設を捉える場合にも示唆的であり、今後の公共文化 施設を考える上でも重要な内容を含んでいると考えられる。

\section{注}

注 1) 例えば、五十嵐太郎, 山崎亮編著『3.11 以後の建築 - 社会と建築家の新 しい関係』(学芸出版社 2014. 11) など様々な東日本大震災以降の建築の在り 方、建築家の在り方について様々な議論がなされている。さらに新建築 2015 年 1 月号において建築家塚本由晴氏は、論文『非施設型空間と补ワークーふる まいを開放する建築一』によって震災後によくみられるようになったまちつ くりなどから生まれる小さな建築を非施設型の建築とよび、その祄ワークから 震災後の新しい公共建築を再構築することについて語っている。

注 2) 本論では、地域の人々が集まり、余腵活動や学習、自治活動を行うと共に、

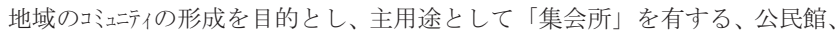
コミュライーゼタ一、生涯学習センターなど公立の集会施設を地域集会施設と定義し、 その建築設計論を資料対象としている。公民館、コミュニテイーセ多、生涯学習ゼター は「地域住民のための集会を中心とした場」ではあるが、制度により各々の 目的・機能あるいは管理運営等の点では異なっている。しかしいずれも公民 館を原形とし、現代では複合施設として、地域のコミュ二テ施設へ発展してきた 地域集会施設であることから、これらを分析の対象としている。

注 3）本論で扱う公共性・地域性に関する内容は、既報の研究、井上翔太, 谷 川大輔：現代日本の公立劇場・本一川の設計論における主題とその具体化 公立 文化施設の設計論における領域構成による地域性とビ゙ディイグタイ゚ (2) , 日 本建築学会計画系論文集, N0. 725, 2016.7 のP2 「1.3 本論における地域性と 公共性」及び注 23 から注 26 で詳述している。

注 4) 新建築誌 2013 年 3 月号において建築家乾久美子氏、藤本壮介氏、平田晃 久氏は対談『「場をつくる力」を支える建築の役割』では、「みんなの家」を 巡って東日本大震災以降の地域施設の在り方について議論を行っている。

注 5) ここで言う建築家とは、主に建築作品及び建築論をジャーナリズムに発表する ことによって、建築の表現活動としている設計者を指している。本論では特
に戦後「新建築」誌を資料とし、実際に設計した建物が紙面に揭載され、写 真や図面と同時にその建物の設計に関する論説が掲載さている設計者を「現 代日本の建築家」としている。限定的な範囲での考察ではあるが、相対的に 現代日本の建築家の設計思想を批評しうるものと考えている。

注 6) 本論では建築家の論説うち、戦後「新建築」誌に、設計した建物（写真 や図面）が同時に掲載された論説で、かつ建築物の設計おける建築家の設計 思想が明確に読み取れるものを建築家の「建築設計論」として分析している。 解説文であっても建築家の設計意図、設計思想が明確に読み取れるものは資 料対象としている。また建築家の論説には、建物の形態、機能、管理に焦点 を合わせたものや、設計に至る背景の説明、建築を通じた地域論や文化論に 関する内容もあるが、その中でも地域と接点をもつ主題として明確に読み取 れ、具体化に結びつけている論説は建築設計論としている。

注 7) ここで建築家の社会的枠組みに関する主張として読み取れるものとは、 建築の設計においていかなる水準で社会との接点を持たせることができる といった、建築家にとっての外的水準に関する思考が読み取れる箇所である。 この外的水準とは、社会状況、都市状況、あるいは私たちの日常生活や生活 水準といった広い意味での環境を、建築を成立させる背景または合理として いるものである。これに対し、建築家の内的水準にのみ関わる主題とは、例 えば、自身の空間に関する概念・价ジといった創作活動における建築家の 内面世界に重きをおいた言説である。したがって本論では、このような内的 水準にのみ関わる主題は、地域とは直接的な関連はないと考光分析対象とし て取り上げていない。

注 8) 建築家の考える地域性を、地域と接点をもつ主題とその主題の領域構成 よって分析された具体化との対応によって考察することから、本論ではそれ を「領域構成による地域性」としている。

注 9）公民館について、例えば『広辞苑』(岩波書店, 2008) には、「社会教育法 に基づき、市町村に設置され、住民のために実生活に即した教育・学術・文 化に関する各種事業を行う施設。」とある。参考文献とした、浅野平八著： 地域集会施設の計画と設計（理工学者, 1995）には、公民館から発展した地 域集会施設の歴史と役割が述べられている。

注 10）1947 年制定の教育基本法（社会教育）第十二条 2 では「国及び地方公共 団体は、図書館、博物館、公民館その他の社会教育施設の設置、学校の施設 の利用、学習の機会及び情報の提供その他の適当な方法によって社会教育の 振興に努めなければならない。」とある。また 1949 年制定の社会教育法には、 第五章 公民館（目的）第二十条「公民館は、市町村その他一定区域内の住 民のために、実際生活に即する教育、学術及び文化に関する各種の事業を行 い、もつて住民の教養の向上、健康の増進、情操の純化を図り、生活文化の 振興、社会福祉の増進に寄与寸ることを目的とする。」と公民館が定義され ている。さらに 1959 年に告示された公民館の設置および運営に関する基準 などの様々な法令によって、公民館の水準の維持や向上が図られている。

注 11) 1990 年制定の生涯学習振興法 (地域生涯学習振興基本計画) 第 5 条には、 「都道府県は、当該都道府県内の特定の地区において、当該地区及びその周 辺の相当程度広範囲の地域における住民の生涯学習の振興に資するため、社 会教育に係る学習（体育に係るものを含む。）及び文化活動その他の生涯学 習に資する諸活動の多様な機会の総合的な提供を民間事業者の能力を活用し つつ行うことに関する基本的な構想を作成することができる」とある。

注 12）三国政勝，中村攻：「新旧住民の利用から見た集会所および公民館の性 格 - 混住地域における居住環境設備の課題 その 2-」日本建築学会計画系論 文報告集 No. 367, pp. 63-71, 昭和 61 年 9 月

注 13）西野達也, 神門香菜, 平野吉信 :「中国地方における市町村合併に伴う 公民館の再編状況とまちづくり拠点化に関する考察」日本建築学会計画系論 文集 No. 75, pp. 2537-2545, 2010. 11

注 14）勝又啓太, 浅野平八：「公民館建築における听゙ー空間の展開過程」日本 建築学会計画系論文集 No. 665, pp. 1231-1240, 2011.7

注 15) 小川次郎, 坂本一成:「公共文化施設における建築の構成とビ゙ル゙゙ イン゙゙タイ゚ ーヴオリュームの複合から見た建築の構成形式に関する研究」日本建築学会計画系 論文集 No. 486, pp. 79-88, 1996.8

注 16）太田英和, 近藤正一, 夏目欣昇, 若山滋 :「日本モダニズム創世期における 建築家の言説の論理構造」日本建築学会計画系論文集 No, 578, pp. 213-218, 2004. 4,

注 17) 竹内正明：「戦後日本における建築ジャーナリズムへの批判的言説について」 日本建築学会計画系論文集 No. 590, pp. 137-143, 2005. 4

注 18）奥山信一, 坂本一成：「戦後「新建築」誌にみられた建築家の住宅観 建築家の住宅論に関する研究」日本建築学会計画系論文報告集 No, 428, pp. 125-135, 1991. 10

注 19）谷川大輔, 奥山信一：「現代日本の建築家の設計論における公共性一 建築設計論における社会的枠組みに関する研究」日本建築学会計画系論文集 
No. 550, pp157-164, 2001. 12, 谷川大輔, 佐々木英子, 奥山信一 : 「市庁舎建築 の設計論における領域構成からみた地域性 - 建築設計論における社会的枠組 みに関する研究 (2)」日本建築学会計画系論文集 No. 595, pp. 25-32, 2005.9 注 20) 本論でビルデイングタイ゚ とは主に、建築計画学等で用いられてきた（博物館、 劇場・ホール、図書館といった）いわゆる主要用途別（機能上）の建築型を指 している。本論では、後に、複数のビルデイダタイプの設計論での分析結果を 比較・検討することで、ビルデイダタイプを横断した相対的な地域への考えや、 今後の公共文化施設のあり方を検討する指針を得ることを目指している。

注 21）井上翔太，谷川大輔：「公立博物館建築の設計論における地域との関わ りをもつ主題とその具体化 公共文化施設の設計論における領域構成による 地域性とビルデイタグタイ゚ ，日本建築学会計画系論文集 No. 718, pp. 2843-2853, 2015. 12, 井上翔太 , 谷川大輔：「現代日本の公立劇場・机ルの設計論における 主題とその具体化 公共文化施設の設計論における領域構成による地域性と ビルデイングタイプ (2)，日本建築学会計画系論文集 No. 725, 2016.7

注 22）本論では、一般建築ジャーナリズムを現代の建築家の最も自由で活発な表現 領域であるという前提のもとに、それらのなかで最も代表的だと思われるも ののひとつであり、しかも長期にわたって継続的に発行されている「新建築」 誌を資料対象としている。公共文化施設が制度・政策の影響を大きく受ける ことなどを考慮して、現在の政治制度となった戦後（1945 年）以降を「現代」 として捉え、1945 年から 2016 年（現在）までを対象期間としている。この ような限定された範囲による報告であるため、現代の建築家の地域集会施設 に関する言語的活動をすべて把握できたと言えないが、こうした研究をさら に深めるための手がかりを提案するという点では、学術的研究の試みになり うると著者らは考えている。

注 23）西山外三氏は『西山外三 :「「戦後『新建築』誌にみられた建築家の創作 の主題」に対する討論」日本建築学会計画系論文集 第 461 号, pp. 199-200, 1994 年 7 月 は、現代の複数の建築家の設計思想を分析する資料として、戦 後「新建築」誌を用いることに対し批判的な意見を述べている。これに対し 奥山信一らは『奥山信一，持田英明，坂本一成：「「戦後『新建築』誌にみら れた建築家の創作の主題」についての西山外三氏の討論に対する回答」にお いてその妥当性を述べている。筆者らは、これらを再検討した上で奥山信一 らの回答を支持する立場で、戦後「新建築」誌を現代日本の建築家の設計論 の資料対象としている。例えば、「編集者の意向により、掲載事例が決定し ている」という指摘に対しても、筆者らも「建築家の作品発表に関わる論説 を検討しようとする場合、前提となるジャー片ズムの性格である」と考え『新 建築』誌を資料対象としている。

注 24）文部科学省 HP「公民館の振興」http://www. mext. go. jp/a_menu/01_1/08 052911/001. htmによる。地域集会施設の建築設計論の分析にあたり、本論で は作品発表時（建設年代）をもととした通時的傾向による分析のみを行って いる。この他、建物の立地場所（都市と地方など）によるちがい、規模（床 面積や複合する機能など）によるちがい、施設形態（運営、管理など）によ るちがいなどの分析が考えられ、これらの指標により、今後地域集会施設の 建築設計論を詳細に分析することができると考えている。

注 25）本論では、資料とした論説を通読しそれらの内容を相互に比較検討する ことによって、それぞれの地域との関係が明確に読み取れる設計意図を地域 と関わりをもつ主題として抽出している。その際、まず資料とした文章中に 「〜が主題である。」「〜が目的であった。」あるいはそのように読み替え可能 な表現を判断根拠として主題を抽出し、さらに抽出された「主題」のうち、 具体的な地名や地域の特徴を捉えて主題と結びつけているもの、あるいは「地 域」との関連性を読み取ることができる表現が読み取れるものを「地域と接 点をもつ主題」としている。

注 26) KJ 法とは、民族地理学の分野で川喜田二郎氏によって考案されたものと してよく知られており、何らかの問題提起から状況把握、そしてそれに対寸 る解決方法の実施検証のプ呗までの一連の方法を言う。本論では、上記の 中で、ある問題をめぐって関係のありそうな情報を集め、定性的データとし意 味の分かるような全体像とするまでのプ呶を狭義での KJ 法としている。資 料とした設計論から抽出した主題をカード化し、意味の近いもの同士をグループ 化し、さらにそれぞれの関係性を検討して意味内容の関係図を描いている。 この分析では、著者らが客観性の高い内容であると判断できるまで、複数人 が繰り返し分析を行っている。このように KJ 法は、複数の建築家の総体的 かつ相対的な思考の枠組みや関係図を示寸ために用いているが、個々の言説 がもっているダ什ミ゙ム（文脈や雰囲気）は、グループ化した意味内容の中に含 まれ読み取ることは難しい。また本論では、主題の具体化の分類についても KJ 法を用いてグループ化し、領域的に整理を行っている。

注 27）本論では、地域集会施設の建築設計論における地域と接点をもつ主題と その具体化の内容を分析するにあたって設定したカケゴリに以下のような括弧 を用いている。
『』地域と接点をもつ主題の意味内容のカテゴリ項目

《》地域と接点をもつ主題の意味内容のカテゴリ項目

第 1 水準

【】地域と接点をもつ主題の意味内容のカテゴリ項目 第 2 水準 第 3 水準 [ ] 地域と接点をもつ主題の意味内容のカテゴリ項目 第 4 水準

注 28）ここでのカテゴリー項目のキーワードは、1973 年に東京公民館資料作成委員会 によって作成された『新しい公民館像をめざして』、いわゆる『三多摩テーゼ』 における公民館とは何か－公民館 4 つの役割 - 「1. 住民の自由なたまり場、 2. 住民の集団活動の拠点、3 住民にとっての「私の大学」、4. 住民による文 化創造のひろば」を参照している。

注 29） 2 章 1 節の（）内の数字は、図 2 のなかの数字に一致する。各々の数字 は資料とした論文の通し番号であり、ひとつの論説より複数の主題が抽出さ れたものは、さらに添え番号をつけた。

注 30）ここで「中心」とは、地域と接点をもつ主題の意味内容の空間配置にお ける「中心」を示している。本論では、複数人で KJ 法を用いて分析を行い、 意味内容の関係において、他のグルプと関係が多いもの、あるいは同時に語 られることが多いがルー゚ が意味内容の中心であるとして図の中央に配置して いる。

注 31）ここでの数量的に整理し、集計、分析する方法は、地域と接点をもつ主 題の具体化の大枠としての傾向は読み取ることができるが、資料毎の特徴的 な方法（例えば、大きな傾向とは異なるが、時代を変革したような特徴的な 方法）は、同時に表示することは難しいと考えている。

\section{参考文献}

1）日本公民館学会編：公民館のデザイ 学びをひらき、地域をつなぐ，エ任゙ル 研究所, 2010

2）日本公民館学会編：公民館・コミュニテイ施設ハトドブック，エ佇゙ル研究所，2010

3）小和田武紀編：公民館図説, 岩崎書店, 1954

4）河野通祐：公民館 建築設計のための手引き, 井上書院, 1972

5）横山宏, 小林文人：公民館史資料集成：工仕”炻开究所, 1986

6) 浅野平八：地域集会施設の計画と設計, 理工学社, 1995

7）谷口汎邦ほか：建築計画・設計シリーズ11 公民館・コミュニテイセンター，市ヶ谷出版 社, 1996

8）日本建築学会編：建築設計資料集成 集会・市民步-ビス，丸善，2002

9）新建築学体系編集委員会編: 新建築学体系 21 地域施設計画, 彰国社, 1984

10）文部科学省 国立教育政策研究所 社会教育実践研究也り夕一：平成 24 年度 公 民館に関する基礎資料, 2013

11）川喜田二郎：発想法 創造性開発のために, 中央公論社, 1967

12) 川喜田二郎：KJ 法 混沌をして語らしめる，中央公論社, 1986 


\title{
THOUGHT ON DESIGN THEORIES OF PUBLIC HALL \\ BY CONTEMPORARY JAPANESE ARCHITECTS
}

Study on regionality from the point of view of space composition and building types

in design theories on public architecture (3)

\author{
Shota INOUE* , Shota TOGE** and Daisuke TANIKAWA *** \\ * Shimane prefectural government, M.Eng. \\ ** JDC Corporation \\ *** Assoc. Prof., Faculty of Eng., Dept. of Architecture, Kindai Univ., Dr.Eng.
}

This study is to illustrate thought on regionality from the point of view of space composition in design theories on Public Hall by contemporary Japanese architects, Through the investigation of their published articles after the Second World War. Public Hall is important to local communities as "open regionalism facilities". After the Great East Japan Earthquake, The designers of public architecture need to think for the local community. Recently, Public architecture was developed every major application (Building types). So, The thinking about the relationship between architecture and regions is the most important for the contemporary Japanese architects. Therefore, this report were described about the thinking of relationship between architecture and regions on design theories on Public Hall. Further after this paper, the some design theories of several building types (Public Museum, Public Theater, Public Hall, Public Library, etc.) are going to be compared.

Firstly, the contents each design theory on Public Hall were analyzed, and several descriptions of "The subject" were extracted (Fig.1). Next, the meaning of these comments was analyzed by applying the method created by Jiro Kawakita. Then, there were drawn a relationship diagram and 5 groups of meaning were found (Fig.2). Next, those meanings were divided into two different groups (Fig.2) ; "Phenomenon value" and "Physical value". Then, the change of that relationship in terms of time was analyzed (Table 1).

Secondly, the contents each design theory were analyzed again, and several descriptions of "The Realization by space composition" were extracted. And the space compositions were analyzed. So, these were classified into 2 space compositions (Table 2); "Singular area" and "Plural areas". Then Singular area was classified into 3 areas; "Inside", "Exterior" and "Outside". So Plural areas were classified into 2 areas; "In site" and "Out site". "In site" is things that have no relationship with "Out site". "Out site" is things that have relationship with "Out site". Furthermore each Plural areas were classified into 2 areas more ; "Adjacency" and "Non-adjacency". As a result, "Plural areas" is the most large (Table 2). Then, the change of that relationship in terms of time was considered (Table 3).

Finally, Between "The subject" and "The Realization by space composition" were analyzed (Table 4). Then, Relationships of "Phenomenon value and Plural areas" are large. Next, from the detailed analysis, 3 Patterns were found (Table 5). (1) The subjects with Phenomenon value, "Base of a group activity - Creation of much activity" and "Free space - Opening to a citizen", are represented by "In site-Adjacency". (2) The subjects with Phenomenon value, "Construction of the community - Solution to social problem", are represented by "Exterior". (3) The subjects with Physical value, "Continuation with the natural scenery", are represented by relationship by "Out site-Non-adjacency". Further, the change of that relationship in terms of time was considered (Table 6). So, The thought on regionality of the designers of Public Hall has changed from around 2000.

Consequently, a definite meaning about thought on regionality in design theories on Public Hall was found. In this particular study, we have pointed out the design ideas of contemporary Japanese architects about public architecture after Second World War. 